\title{
Physiological testing of a beverage system designed for long-haul air travel
}

\author{
James D Cotter ${ }^{1 *}$, Evelyn B Parr ${ }^{1}$, Patrick Silcock², Fiona Nyhof ${ }^{2}$, Nancy J Rehrer ${ }^{1}$ \\ From 15th International Conference on Environmental Ergonomics (ICEE XV) \\ Portsmouth, UK. 28 June - 3 July 2015
}

\begin{abstract}
Introduction
Long-haul air travel imposes multiple stressors, arising from prolonged immobility, low humidity, modest hypobaria, circadian disruption and oxidative stress from food and cosmic radiation [1]. We developed a beverage system (Flyhidrate ${ }^{\mathrm{TM}}{ }^{\mathrm{a}}$ ) to counteract such effects, using ingredients shown in previous research to be effective when used acutely in achievable quantities, with low risk of adverse effects in unscreened populations. Flyhidrate is a $3 \% 330 \mathrm{~mL}$ beverage system based on sodium-citrate and sodium-chloride for hydration, with supplemental ingredients (esp. fruit extracts) for early, mid and/or late phase flying effects. The aim of this study was to determine the physiological effectiveness of Flyhidrate in lab trials that simulated long-haul flying to the extent possible in our testing facilities.
\end{abstract}

\section{Methods}

In a double-blind, placebo-controlled, crossover design, 12 male adult volunteers (mean (SD): mass 76 (16) kg) underwent two 7-h trials, at least one week apart (both at $\left.24.2(0.1){ }^{\circ} \mathrm{C}, 30.4(1.5) \% \mathrm{rh}\right)$. Participants were seated except for two 10-min periods used for micturition. In each trial, participants consumed a standardised snack, meal and normal fluids $(430 \mathrm{~mL}$ water, tea and coffee; ad libitum in first trial, then repeated in second trial), and $330 \mathrm{~mL}$ of Flyhidrate or equal volumes of equivalently-coloured and flavoured placebo (143 kJ energy and $0.8 \mathrm{mMol}$ sodium) at $0.3,3.0$ and $5.7 \mathrm{~h}$ (i.e., $990 \mathrm{~mL}$ of each beverage). Each Flyhidrate 330-mL drink, depending on its role, contains $298-913 \mathrm{mg}$ polyphenols, 0-48 g caffeine, $255-288 \mathrm{~kJ}$ energy and $21.7 \mathrm{mMol}$ sodium, and has an osmolality of $336-378 \mathrm{mOsmol} / \mathrm{kg}$.

\footnotetext{
* Correspondence: jim.cotter@otago.ac.nz

${ }^{1}$ School of Physical Education, Sport and Exercise Sciences, University of

Otago, Dunedin, New Zealand

Full list of author information is available at the end of the article
}

\section{Results}

Urine output across $7 \mathrm{~h}$ was $0.23 \pm 0.16 \mathrm{~L}$ (mean $\pm 95 \%$ $\mathrm{CI} ; p=0.02)$ lower in Flyhidrate than in Placebo (1.05 $(0.48)$ vs. $1.28(0.34) \mathrm{L})$. Approximately half $(0.13 \mathrm{~L})$ of this difference was evident after the first drink ( $p=$ 0.01 ). Total body water loss, assessed from bioimpedance analysis, was $0.4 \pm 0.4 \mathrm{~L}$ less in Flyhidrate $(p=$ $0.05)$, and plasma volume increased by $3.0 \pm 2.8 \%$ ( $p=$ $0.04)$ more in Flyhidrate than in Placebo (4.1 vs $1.1 \%$ ). Flyhidrate provided no clear effect on the seatinginduced increase in calf girth $(0.5$ vs $1.3 \% p=0.10)$ or ankle girth ( 0.2 vs $0.8 \% ; p=0.23)$. Effects on heart rate were similarly unclear $(p=0.70)$. Oxidative stress, as indicated from plasma concentration of Advanced Oxidative Protein Products, increased by $171 \%$ for Flyhidrate and $199 \%$ for Placebo, without measurable difference $(p=0.50)$.

\section{Discussion}

Fluid balance and plasma volume were maintained more effectively with Flyhidrate than with a matched volume of placebo beverage, despite the consumption of other fluids. These findings concur with those from a field trial of another sodium-based beverage in long-haul flying [2]. Other potential physiological effects from supplemental ingredients were not discernible in these laboratory trials. Controlled trials involving a more complete representation of the stressors of long-haul air travel appear necessary to examine such effects.

\section{Conclusion}

The customised beverage system maintained fluid balance and plasma volume more effectively than did a placebo beverage, but other potential benefits were unclear in this setting. 


\section{Acknowledgement and disclosure}

The concept of this beverage system and funding for the study was provided by Flyhidrate Ltd, New Zealand. Thanks to Michael Dessoulavy for oxidative stress analyses.

\section{Authors' details}

'School of Physical Education, Sport and Exercise Sciences, University of Otago, Dunedin, New Zealand. ${ }^{2}$ Department of Food Science, University of Otago, Dunedin, New Zealand.

Published: 14 September 2015

\section{References}

1. Greenleaf JE, Rehrer NJ, Mohler SR, Quach DT, Evans DG: Airline chair-rest deconditioning: induction of immobilisation thromboemboli? Sports Medicine 2004, 34(11):705-725.

2. Hamada K, Doi T, Sakurai M, et al: Effects of hydration on fluid balance and lower-extremity blood viscosity during long airplane flights. JAMA 2002, 287:844

doi:10.1186/2046-7648-4-S1-A61

Cite this article as: Cotter et al:: Physiological testing of a beverage system designed for long-haul air travel. Extreme Physiology \& Medicine 2015 4(Suppl 1):A61.

\section{Submit your next manuscript to BioMed Central} and take full advantage of:

- Convenient online submission

- Thorough peer review

- No space constraints or color figure charges

- Immediate publication on acceptance

- Inclusion in PubMed, CAS, Scopus and Google Scholar

- Research which is freely available for redistribution

Submit your manuscript at www.biomedcentral.com/submit 